mgr inz. Maciej Wieczorek

dr hab. inz. Mirosław Lewandowski

Politechnika Warszawska

\title{
Dobór i optymalizacja konfiguracji zasobnika trakcyjnego
}

\author{
$W$ artykule przedstawiono algorytm doboru magazynów energii elektrycznej. \\ Wybór HESS pozwala na spetnienie warunków obciqżenia w sposób optymalny. \\ Jednak ustalenie konfiguracji urzqdzeń $w$ systemie staje się bardzo złożonym \\ zagadnieniem optymalizacyjnym. Przedstawiono propozycje rozwiazania tego \\ problemu z zastosowaniem algorytmu genetycznego.
}

\section{Wstęp}

Zasobniki energii (ESS, ang. energy storage system) stają się jednym z najważniejszych elementów zwiększających ogólną wydajność układów, w których są stosowane. Spektrum zastosowań jest bardzo szerokie: od systemu elektroenergetycznego, pojazdów trakcyjnych do elektroniki mobilnej. Zasobniki energii stosowane $\mathrm{w}$ trakcyjnych systemach elektroenergetycznych umożliwiają zarządzanie energią otrzymaną $w$ trakcie hamowania odzyskowego oraz wspomaganie $\mathrm{w}$ stanach obniżonego napięcia $\mathrm{w}$ sieci trakcyjnej [1]. Magazyny energii o mocy rzędu MW znajdują zastosowanie $\mathrm{w}$ systemie elektroenergetycznym, gdzie wykorzystywane są do wyrównywania obciążeń oraz poprawy jakości energii [2]. Prace nad konstrukcją akumulatorów elektrochemicznych, zwłaszcza w technologii litowo-jonowej, wskazują na możliwość zwiększenia ich gęstości energii, która w chwili obecnej wynosi ok. $200 \mathrm{Wh} / \mathrm{kg}$, nawet o $300 \%$. Nie mniej, nie są one w stanie dorównać paliwom kopalnym (olej napędowy $-13000 \mathrm{Wh} / \mathrm{kg}$ ). Stają się natomiast poważną alternatywą w przypadku zasilania pojazdów poruszających się $\mathrm{w}$ trybie miejskim, $\mathrm{w}$ razie ograniczenia dostępu do dostaw ropy oraz $\mathrm{w}$ dobie przyspieszających zmian klimatu.. Kolejnym problemem w przypadku poszczególnych typów zasobników energii są ograniczenia nie tylko magazynowanej energii, ale także maksymalnej mocy, jaką mogą oddać i przyjąć, liczby cykli, ceny itd. Korzystając z mnogości technologii dostępnych obecnie na rynku oraz różnic w charakterystykach różnych typów zasobników można tworzyć hybrydowe zasobniki energii (HESS, hybryd energy storage system). HESS jest połączeniem dwóch lub więcej typów zasobników w jednym systemie. Takie rozwiazzanie pozwala na wykorzystanie zalet poszczególnych magazynów energii i ukrycie ich wad.

Wykorzystanie HESS wymaga opracowania nowych metod doboru i wymiarowania elementów w systemie $\mathrm{w}$ zależności od rodzaju aplikacji w jakiej będzie wykorzystywany. W artykule zostanie przedstawiona metoda optymalizacji konfiguracji systemu w oparciu o algorytm genetyczny.

\section{Dobór zasobników do obciążenia}

Dobór parametrów zasobnika rozpoczyna się od określenia parametrów układu obciążenia. Podstawowe wielkości konieczne do ustalenia to napięcie zasilania $U_{D C}$, energia $E$, która ma być zgromadzona w zasobniku, maksymalna moc obciążenia $P_{\max }$, maksymalna moc jaką układ obciążenia będzie oddawał do zasobnika, maksymalny przyrost mocy w czasie $d P / d t_{\max }$ oraz temperaturowe warunki pracy układu. Uwzględnić należy również ograniczenia przekształtnika energoelektronicznego, przez który zasobnik jest przyłączony do systemu, jeżeli taki występuje. W przypadku np. superkondensatorów, gdzie wartość napięcia na wyjściu jest $\mathrm{w}$ dużym stopniu zależna od stanu naładowania, ograniczona zdolność przekształtnika do podwyższania napięcia nie pozwala na pełne wykorzystanie jego pojemności [3].

W przypadku wyboru jednolitego typu zasobników spełnienie podanych wyżej parametrów nie jest problemem. Może jednak nastapić znaczne przewymiarowanie w przypadku jednego z parametrów. Nie będzie to rozwiązanie optymalne, zwłaszcza pod względem kosztów ponieważ obecnie zasobniki energii są najdroższym elementem wielu urządzeń. Wybór HESS pozwala na spełnienie warunków obciążenia w sposób optymalny. Jednak ustalenie konfiguracji urządzeń w systemie staje się bardzo złożonym zagadnieniem optymalizacyjnym. Dlatego do rozwiązania tego problemu wybrano algorytm genetyczny.

\section{Implementacja algorytmu oraz wyniki badań}

W celu sprawdzenia poprawności działania algorytmu genetycznego wykonano badanie doboru zestawu zasobników do zasilania lekkiego, autonomicznego, elektrycznego pojazdu miejskiego.

\section{- Parametry obciążenia}

Przyjęto, że pojazd o masie do $1000 \mathrm{~kg}$ aby przejechać dystans ok. $80 \mathrm{~km}$ w cyklu miejskim potrzebuje energii ok. $20 \mathrm{kWh}$. Napięcie $U_{D C}=300 \mathrm{~V}$. Wartości $P_{\max }=75 \mathrm{~kW}$ i $d P / d t_{\max }=150 \mathrm{~W} / \mathrm{s}$ wyznaczono na podstawie krytycznego przebiegu mocy obciążenia pojazdu (rys.1). 


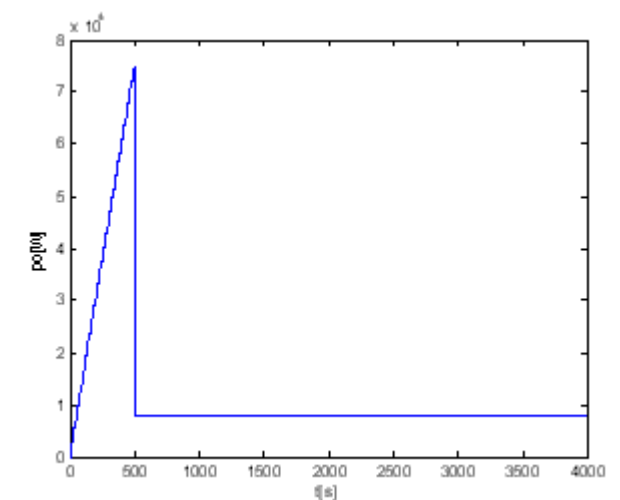

Rys. 1. Krytyczny przebieg mocy obciążenia pojazdu.

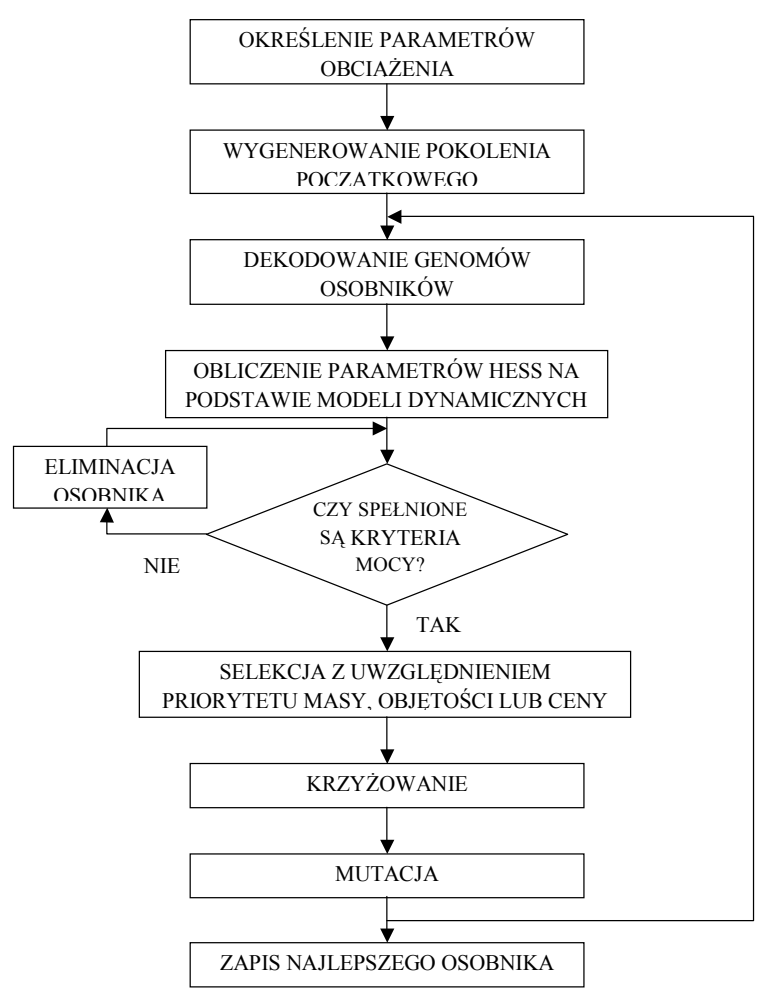

Rys. 2. Struktura algorytmu genetycznego.

\section{- Parametry elementów HESS}

Badania optymalizacji doboru wykonano dla konfiguracji 3 typów zasobników w systemie: superkondensatora jako zasobnika o największej gęstości mocy, akumulatora litowo-jonowego jako zasobnika o największej gęstości energii oraz akumulatora kwasowoołowiowego jako zasobnika o najniższej cenie w stosunku do gromadzonej energii.
Sprawność przekształtników DC/DC przyjęto na poziomie 0,8 , masę $\mathrm{m}_{\mathrm{c}}=0,2 \mathrm{~kg}$ i cenę $5 \$$. W układzie wykorzystywany jest przekształtnik półmostkowy typu buck-boost. W związku z tym napięcie zasobnika powinno być nie wyższe niż napięcie $U_{D C}$ i wyższe niż $0,5 U_{D C}$ [4]. Przyjęto zatem, że liczba szeregowo połączonych pojedynczych celek zasobników jest stała i równa:

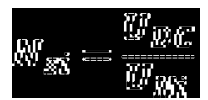

Gdzie $N_{s i}$ i $U_{N i}$ oznaczają odpowiednio liczbę szeregowo połączonych celek i-tego zasobnika i napięcie pojedynczej celki i-tego zasobnika. Optymalizacji jest poddawana liczba równolegle połączonych gałęzi o liczbie celek wyznaczonych wg (1). W algorytmie istnieje możliwość zmiany priorytetów optymalizacji masy, objętości i ceny, w zależności od potrzeb konkretnego zastosowania.

\section{- Wyniki obliczeń algorytmu}

Dla priorytetu ceny:

a)

b)
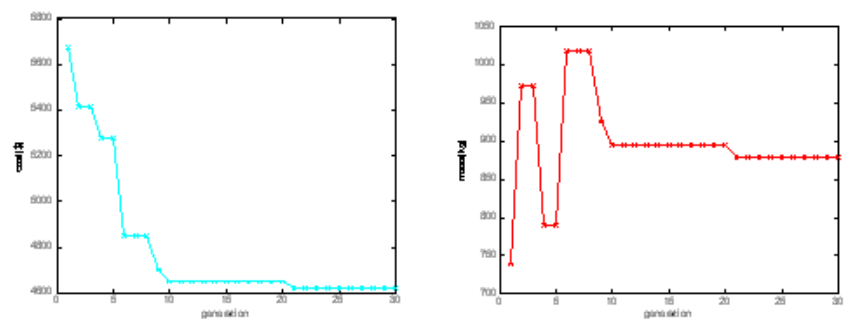

c)

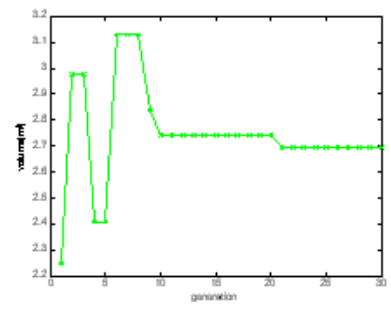

$$
\begin{aligned}
& \mathrm{N}_{S \mathrm{UC}}=0 \\
& \mathrm{~N}_{\mathrm{pUC}}=0 \\
& \mathrm{~N}_{\mathrm{SLI}}=83 \\
& \mathrm{~N}_{\mathrm{pLI}}=20 \\
& \mathrm{~N}_{\mathrm{SLA}}=50 \\
& \mathrm{~N}_{\mathrm{pLA}}=52
\end{aligned}
$$

Rys. 3. Wyniki działania algorytmu dla 30 pokoleń i 100 osobników w pokoleniu. Parametry najlepszych osobników w poszczególnych pokoleniach: a) cena, b) masa, c) objętość.

Tabela 1. Parametry zasobników uwzględnionych w optymalizacji.

\begin{tabular}{|l|l|l|l|}
\hline parametry & superkondensator & Akumulator li-ion & Akumulator lead-acid \\
\hline Napięcie znamionowe [V] & 2,7 & 3,6 & 6 \\
\hline $\begin{array}{l}\text { Znamionowy prąd rozłado- } \\
\text { wania [A] }\end{array}$ & 30 & 2,2 & 1,3 \\
\hline $\begin{array}{l}\text { Maksymalny prąd rozłado- } \\
\text { wania [A] }\end{array}$ & 81 & 4,4 & 4,5 \\
\hline Pojemność & $1200[\mathrm{~F}]$ & $2,2[\mathrm{Ah}]$ & $1,3[\mathrm{Ah}]$ \\
\hline Masa [kg] & 0,26 & 0,044 & 0,31 \\
\hline Objętość [m $\left.{ }^{3}\right]$ & $2,1 * 10^{-4}$ & $1 * 10^{-4}$ & $8^{*} 10^{-4}$ \\
\hline Cena [\$] & 30 & 2 & 0,5 \\
\hline
\end{tabular}


Dla priorytetu masy:

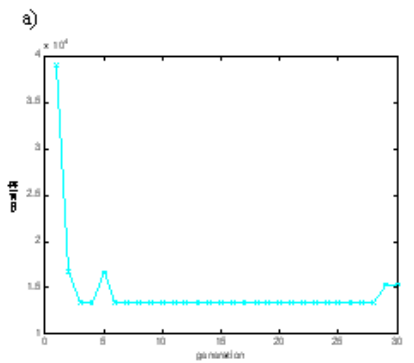

c)

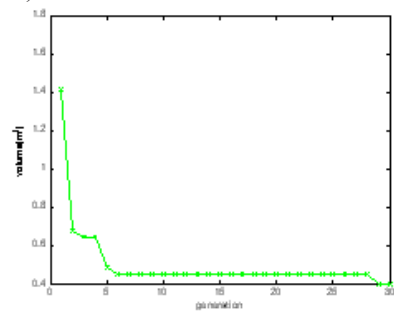

b)

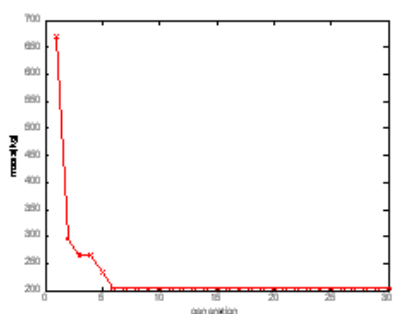

$\mathrm{N}_{\mathrm{sUC}}=111$

$\mathrm{N}_{\mathrm{puC}}=2$

$\mathrm{N}_{\text {sLI }}=83$

$\mathrm{N}_{\mathrm{pLI}}=40$

$\mathrm{N}_{\text {sLA }}=0$

$\mathrm{N}_{\mathrm{pLA}}=0$

\section{Podsumowanie}

Wraz z rozwojem technologii magazynowania energii elektrycznej, spektrum zastosowań zasobników hybrydowych będzie rosło [5]. Konieczne zatem będzie opracowanie nowych metod i kryteriów doboru elementów HESS. Jest to złożone zagadnieniem ze względu na różnice $\mathrm{w}$ dynamice różnych typów zasobników. Algorytm genetyczny jest dobrym rozwiązaniem ze względu na swoją prostotę oraz możliwość implementacji problemu o dowolnej złożoności.

\section{Biliografia}

1. Mohamed I. Daoud, A. S. Abdel-Khalik, A. Elserougi, S. Ahmed, A.M. Massoud; DC Bus Control of an Advanced Flywheel Energy Storage Kinetic Traction System for Electrified Railway Industry. Industrial Electronics Society, IECON 2013 - 39th Annual Conference of the IEEE, vol., no., pp.6596,6601, 10-13 Nov. 2013.

2. Younghyun Kim, Jason Koh, Qing Xie, Yanzhi Wang, Naehyuck Chang, Massoud Pedram; A scalable and flexible hybrid energy storage system design and implementation. Journal of Power Sources 255 (2014) $410 e 422$.

3. Lewandowski M., Orzyłowski M.; Zastosowanie rachunku różniczkowego ułamkowego rzędu do modelowania dynamiki superkondensatorów. Przeglad Elektrotechniczny 8/2014, s.13-17.

4. Schupbach R. M., Balda J. C.; Comparing DC-DC Converters for Power Management in Hybrid Electric Vehicles. IEEE, 2003.

5. Szelag A.; Wplyw napięcia w sieci trakcyjnej $3 \mathrm{kV} \mathrm{DC}$ na parametry energetyczno-

6. trakcyjne zasilanych pojazdów. Instytut NaukowoWydawniczy SPATIUM. $2013 r$. 